\title{
PRINSIP GOOD CORPORATE GOVERNANCE PADA BANK PERKREDITAN
} RAKYAT

\author{
Siswi Wulandari \\ Dosen Fakultas Ilmu Pendidikan dan Pengetahuan Sosial \\ Universitas Indraprasta PGRI Jakarta \\ E-mail : $\underline{\text { siswiwulandari89@yahoo.co.id }}$
}

\begin{abstract}
ABSTRAK
Kajian dalam Penelitian ini adalah penerapan Good Corporate Governance di Bank Perkreditan Rakyat. Good Corporate Governance dibutuhkan sebagai salah satu instrumen pengelolaan manajemen bank yang baik. Dengan pelaksanaan Good Corporate Governance yang efektif maka akan meningkatkan kualitas Sumber Daya Manusia pada BPR. Dengan kualitas Sumber Daya Manusia yang baik maka akan meningkatkan pelayanan bank kepada nasabah. Penelitian ini menggunakan penelitian deskriptif kualitatif. Inti dari Good Corporate Governance adalah moral dan etika yang dibarengi dengan perangkat hukum.

Kata Kunci: Bank Perkreditan Rakyat, Good Corporate Governance, sumber daya manusia.

\section{ABSTRACT}

The study in this research is the application of Good Corporate Governance in Bank Perkreditan Rakyat. Good Corporate Governance is needed as one of the good management instruments of bank management. With effective implementation of Good Corporate Governance, it will improve the quality of Human Resources in BPR. With a good quality of Human Resources will improve the bank service to customers. This research uses qualitative descriptive research. The core of Good Corporate Governance is moral and ethics coupled with the law.
\end{abstract}

Keywords: Bank Perkreditan Rakyat, Good Corporate Governance, Human 


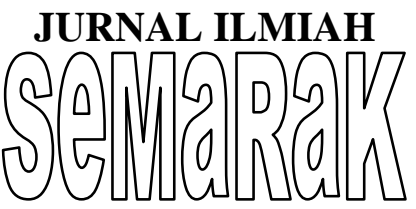

P-ISSN 2615-6849

Jurnal Semarak,Vol. 1,No.1,Februari 2018 , Hal (130-141)

@ Prodi Manajemen Fakultas Ekonomi Universitas Pamulang

\section{PENDAHULUAN}

Pembangunan nasional merupakan upaya pembangunan berkesinambungan dalam rangka mewujudkan masyarakat Indonesia yang adil dan makmur berdasarkan Pancasila dan Undang-Undang Dasar 1945, sebagaimana termaktub dalam Pembukaan Undang-Undang Dasar 1945, yaitu melindungi segenap bangsa dan seluruh tumpah darah Indonesia, memajukan kesejahteraan umum, mencerdaskan kehidupan bangsa serta melaksanakan ketertiban dunia yang berdasarkan kemerdekaan, perdamaian abadi, dan keadilan sosial.

Menghadapiperkembanganperekonomia $\mathrm{n}$ nasional yang senantiasa bergerak cepat, kompetitif, dan terintegrasi dengan tantangan yang semakin kompleks serta sistem keuangan yang semakin maju, diperlukan penyesuaian kebijakan di bidang ekonomi, termasuk perbankan. Berkaitan dengan pelaksanaan pembangunan nasional tersebut, dalam ketentuan Pasal 4 UndangUndang Nomor 7 Tahun 1992 sebagaimana telah diubah dengan Undang-Undang Nomor 10 Tahun 1998 Tentang Perbankan (yang selanjutnya disebut Undang-Undang Perbankan) disebutkan bahwa dalam kaitannya dengan pembangunan, sektor perbankan memiliki fungsi sebagai agen pembangunan (agent of development), yaitu sebagai lembaga yang bertujuan mendukung pelaksanaan pembangunan nasional. Adanya peranan yang demikian membawa konsekuensi bahwa perbankan nasional dituntut untuk selalu dapat memberikan kemanfaatan yang sebesar-besarnya guna meningkatkan pertumbuhan ekonomi dan melakukan pemerataan atas hasil-hasilnya, sehingga tercipta stabilitas nasional yang mengarah kepada peningkatan kesejahteraan masyarakatbanyak.(http://dspace.widyatama. ac.id)

Pengelolaan dana masyarakat yang dilakukan secara profesional akan meningkatkan kepercayaan masyarakat dalam menyimpan uangnya ke bank, oleh karena itu, bank wajib memelihara kepercayaan masyarakat. Jika tidak demikian, akan timbul krisis kepercayaan dan masyarakat akan menarik dananya yang tersimpan di bank. (Abdulkadir Muhammad, 2006 : 241).

Tetapi kejahatan dengan bentuk kecurangan di dunia perbankan yang dilakukan oleh organ perseroan, khususnya pada Bank Perkreditan Rakyat sangat banyak terjadi. Hal ini disebabkan buruknya kualitas Sumber Daya Manusia yang bernaung di Bank Perkreditan Rakyat dan juga belum adanya peraturan perundangundangan yang mengatur mengenai perlindungan nasabah dan Prinsip-prinsip manajemen perseroan yang baik (Good Corporate Governance) yang khusus diperuntukkan bagi Bank Perkreditan Rakyat.

Penerapan prinsip Good Corporate Governance pada perbankan yang merupakan sistem tata kelola perusahaan untuk menciptakan lingkungan yang kondusif terhadap pertumbuhan sektor usaha yang efisien dan berkesinambungan. (Rachmadi Usman, 2001 : 14).

$$
\text { Asas-asas dari Good Corporate }
$$

Governance, yaitu prinsip - prinsip keterbukaan (transparency), akuntabilitas (accountability),pertanggungjawaban(respon sibility),independensi (independency), dan kewajaran (fairness).

Penerapan Good Corporate Governance dapat didorong dari dua sisi, yaitu etika dan peraturan. Dorongan dari etika (ethical driven) datang dari kesadaran individuindividu pelaku bisnis untuk menjalankan praktik bisnis yang mengutamakan kelangsungan hidup perusahaan, kepentingan stakeholders, dan menghindari cara-cara menciptakan keuntungan sesaat. Di sisi lain, dorongan dari peraturan "memaksa" (regulatory driven) perusahaan untuk patuh 


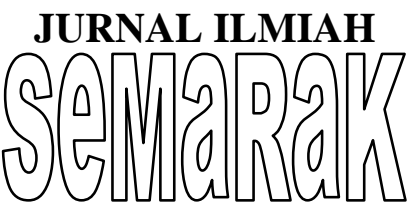

terhadap peraturan perundang-undangan yang berlaku. Kedua pendekatan ini memiliki kekuatan dan kelemahannya masing-masing dan seyogyanya saling melengkapi untuk menciptakan lingkungan bisnis yang sehat. (www.bapepam.go.id). Inti dari Good Corporate Governance adalah moral dan etika yang dibarengi dengan perangkat hukum.

Prinsip-prinsip manajemen perseroan yang baik (Good Corporate Governance) merupakan tugas direksi yang harus terus dikembangkan dalam kepengurusan bank. Hal yang paling relevan dengan pengembangan sistem dan manajemen bank adalah akuntabilitas dari bank itu sendiri. Berdasarkan prinsip tersebut, masing-masing komponen perusahaan, pemegang saham melalui Rapat Umum Pemegang Saham (selanjutnya disebut RUPS), komisaris dan direksi dituntut untuk mengerti dengan baik hak dan kewajiban, kewenangan dan tanggung jawab. Penting untuk selalu diingatkan sehingga masing-masing komponen mampu melaksanakan tugas secara profesional, komitmen yang tinggi, serta integritas profesionalisme yang memadai, yang juga didukung dengan dibuatnya sistem pengawasan dan kontrol. (Frans Satrio Wicaksono, 2009 : 122).

Berdasarkan latar belakang yang telah diuraikan tersebut, pokok permasalahan dalam tulisan ini adalah bagaimana penerapan prinsip GCG di Bank Perkreditan Rakyat.

Berdasarkan pokok permasalahan tersebut maka tujuan penulisan ini adalah untuk mengetahui bagaimana konsep prinsip GCG di implementasikan pada Bank Perkreditan Rakyat.

\section{METODE PENELITIAN}

Metode penelitian yang digunakan dalam penulisan ini adalah metode deskriptif kualitatif yang dilakukan melalui studi pustaka yang menelaah data sekunder berupa buku-buku, jurnal, peraturan perundang-undangan dan referensi lainnya.

Penelitian deskriptif kualitatif merupakan salah satu dari jenis penelitian yang termasuk dalam jenis penelitian kualitatif. Adapun tujuan dari penelitian ini adalah untuk mengungkapkan kejadian atau fakta, keadaan, fenomena, variabel dan keadaan yang terjadi saat penelitian berlangsung dengan menyuguhkan apa yang sebenarnya terjadi. Penelitian ini menafsirkan dan menguraikan data yang bersangkutan dengan situasi yang sedang terjadi, sikap serta pandangan yang terjadi di dalam suatu masyarakat, pertentangan antara dua keadaan atau lebih, hubungan antar variabel yang timbul, perbedaan antar fakta yang ada serta pengaruhnya terhadap suatu kondisi, dan sebagainya.

Menurut Nazir (1988 : 63) metode deskriptif merupakan suatu metode dalam meneliti status sekelompok manusia, suatu objek, suatu set kondisi, suatu sistem pemikiran ataupun suatu kelas peristiwa pada masa sekarang. Tujuan dari penelitian deskriptif ini adalah untuk membuat deskripsi, gambaran, atau lukisan secara sistematis, faktual dan akurat mengenai fakta-fakta, sifat-sifat serta hubungan antarfenomena yang diselidiki.

$$
\text { Menurut Sugiyono (2005 : 21) }
$$
menyatakan bahwa metode deskriptif adalah suatu metode yang digunakan untuk menggambarkan atau menganalisis suatu hasil penelitian tetapi tidak digunakan untuk membuat kesimpulan yang lebih luas.

\section{HASIL DAN PEMBAHASAN}

\section{Tinjauan Umum Bank Perkreditan Rakyat}

Pasal 1 angka 4 Undang-Undang Perbankan menyebutkan:

"Bank Perkreditan Rakyat adalah bank yang melaksanakan kegiatan usaha secara 


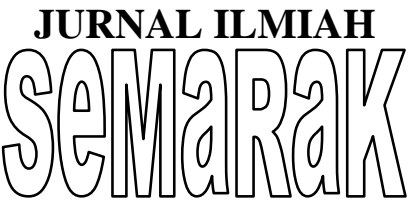

P-ISSN 2615-6849

Jurnal Semarak,Vol. 1,No.1,Februari 2018 , Hal (130-141)

@ Prodi Manajemen Fakultas Ekonomi Universitas Pamulang

konvensional dan/atau berdasarkan Prinsip Syariah yang dalam kegiatannya tidak memberikan jasa dalam lalu lintas pembayaran"

Usaha yang dapat dilakukan oleh BPR, sesuai dengan Pasal 13 Undang-Undang Perbankan, meliputi:

"Usaha Bank Perkreditan Rakyat meliputi:

a. Menghimpun dana dari masyarakat dalam bentuk simpanan berupa deposito berjangka dan atau bentuk lainnya yang dipersamakan dengan itu.

b. Memberikan kredit.

c. Menyediakan pembiayaan bagi nasabah berdasarkan prinsip syariah.

d. Menempatkan dananya dalam bentuk Sertifikat Bank Indonesia (SBI), deposito berjangka, sertifikat deposito, dan atau tabungan pada bank lain.”

Selain kegiatan usaha yang diperbolehkan seperti halnya jenis usahausaha diatas, juga ditentukan ada beberapa larangan yang membatasi kegiatan usaha BPR. Larangan tersebut meliputi usaha menerima simpanan giro dan ikut serta dalam lalu lintas pembayaran, melakukan kegiatan usaha dalam valuta asing, melakukan penyertaan modal, melakukan usaha perasuransian, dan melakukan usaha lain di luar kegiatan usaha seperti di atas. (Hermansyah, 2008 : 151)

\section{Tinjauan Umum Prinsip Good Corporate Governance}

a) Pengertian Prinsip Good Corporate Governance

Good Corporate Governance pada dasarnya merupakan suatu sistem (input, proses, output) dan seperangkat peraturan yang mengatur hubungan antara berbagai pihak yang kepentingan (stakeholders) terutama dalam arti sempit hubungan antara pemegang saham, dewan komisaris, dan dewan Direksi demi tercapainya tujuan perusahaan. Good Corporate Governance dimaksudkan untuk mengatur hubunganhubungan ini dan mencegah terjadinya kesalahan-kesalahan signifikan dalam strategi perusahaan dan untuk memastikan bahwa kesalahan-kesalahan yang terjadi dapat diperbaiki dengan Negara. (Moh. Wahyudin Zarkasyi, 2008 : 36)

b) Prinsip-Prinsip Good Corporate Governance

Secara umum terdapat lima prinsip dasar dari good corporate governance yaitu: (http://jurnalmanajemen.petra.ac.id )

1) Transparency (keterbukaan informasi), yaitu keterbukaan dalam melaksanakan proses pengambilan keputusan dan keterbukaan dalam mengemukakan informasi materiil dan relevan mengenai perusahaan.

2) Accountability (akuntabilitas), yaitu kejelasan fungsi, struktur, sistem, dan pertanggungjawaban organ perusahaan sehingga pengelolaan perusahaan terlaksana secara efektif.

3) Responsibility (pertanggungjawaban), yaitu kesesuaian (kepatuhan) di dalam pengelolaan perusahaan terhadap prinsip korporasi yang sehat serta peraturan perundangan yang berlaku.

4) Independency (kemandirian), yaitu suatu keadaan dimana perusahaan dikelola secara profesional tanpa benturan kepentingan dan pengaruh/tekanan dari pihak manajemen yang tidak sesuai dengan peraturan dan perundangan-undangan yang berlaku dan prinsip-prinsip korporasi yang sehat.

5) Fairness (kesetaraan da kewajaran), yaitu perlakuan yang adil dan setara di dalam memenuhi hak-hak stakeholder yang timbul berdasarkan perjanjian serta peraturan perundangan yang berlaku. 
Esensi dari corporate governance adalah peningkatan kinerja perusahaar melalui supervisi atau pemantauan kinerjc manajemen dan adanya akuntabilitas manajemen terhadap pemangku kepentingar lainnya, berdasarkan kerangka aturan dar peraturan yang berlaku.

\section{Tahap-tahap Penerapan Prinsip Gooc Corporate Governance}

Dalam pelaksanaan penerapan GCG d: perusahaan adalah penting bagi perusahaar untuk melaku kan pentahapan yang cerma berdasarkan analisis atas situasi dan kondis perusahaan, dan tingkat kesiapannya sehingga penerapan GCG dapat berjalar lancar dan mendapatkan dukungan dari seluruh unsur di dalam perusahaan.

Pada umumnya perusahaan-perusahaan yang telah berhasil dalam menerapkan GCG menggunakan pentahapan berikut: (John C Shaw, 2003 : 155).

\section{Tahap Persiapan}

Tahap ini terdiri atas 3 langkah utama: 1) awareness building, 2) GCG assessment, dan 3) GCG manual building. Awareness building merupakan langkah awal untuk membangun kesadaran mengenai arti penting GCG dan komitmen bersama dalam penerapannya. Upaya ini dapat dilakukan dengan meminta bantuan tenaga ahli independen dari luar perusahaan. Bentuk kegiatan dapat dilakukan melalui seminar, lokakarya, dan diskusi kelompok.

GCG Assessment merupakan upaya untuk mengukur atau lebih tepatnya memetakan kondisi perusahaan dalam penetapan GCG saat ini. Langkah ini perlu guna memastikan titik awal level penerapan GCG dan untuk mengidentifikasi langkah-langkah yang tepat guna mempersiapkan infrastruktur dan struktur perusahaan yang kondusif bagi penerapan GCG secara efektif. Dengan kata lain, GCG assessment dibutuhkan untuk mengidentifikasi aspek-aspek apa yang perlu mendapatkan perhatian terlebih dahulu, dan langkah-langkah apa yang dapat diambil untuk mewujudkannya.

GCG manual building, adalah langkah berikut setelah GCG assessment dilakukan. Berdasarkan hasil pemetaan tingkat kesiapan perusahaan dan upaya identifikasi prioritas penerapannya, penyusunan manual atau pedoman implementasi GCG dapat disusun. Penyusunan manual dapat dilakukan dengan bantuan tenaga ahli independen dari luar perusahaan. Manual ini dapat dibedakan antara manual untuk organ-organ perusahaan dan manual untuk keseluruhan anggota perusahaan, mencakup berbagai aspek seperti:
a. Kebijakan GCG perusahaan
b. Pedoman GCG bagi organ-organ perusahaan
c. Pedoman perilaku
d. Audit commitee charter
e. Kebijakan disclosure dan transparansi
f. Kebijakan dan kerangka manajemen resiko
g. Roadmap implementasi

\section{Tahap Implementasi}

Setelah perusahaan memiliki GCG manual, langkah selanjutnya adalah memulai implementasi di perusahaan. Tahap ini terdiri atas 3 langkah utama

yakni:

a. Sosialisasi, diperlukan untuk memperkenalkan kepada seluruh perusahaan berbagai aspek yang terkait dengan implementasi GCG khususnya mengenai pedoman penerapan GCG. Upaya sosialisasi perlu dilakukan dengan suatu tim khusus yang dibentuk untuk itu, langsung berada di bawah pengawasan direktur utama atau salah satu direktur yang ditunjuk sebagai GCG champion di perusahaan.

b. Implementasi, yaitu kegiatan yang dilakukan sejalan dengan pedoman GCG 
yang ada, berdasar roadmap yang telah disusun. Implementasi harus bersifat top down approach yang melibatkan dewan komisaris dan direksi perusahaan. Implementasi hendaknya mencakup pula upaya manajemen perubahan (change management) guna mengawal proses perubahan yang ditimbulkan oleh implementasi GCG.

c. Internalisasi, yaitu tahap jangka panjang dalam implementasi. Internalisasi mencakup upaya-upaya untuk memperkenalkan GCG di dalam seluruh proses bisnis perusahaan kerja, dan berbagai peraturan perusahaan. Dengan upaya ini dapat dipastikan bahwa penerapan GCG bukan sekedar dipermukaan atau sekedar suatu kepatuhan yang bersifat superficial, tetapi benar-benar tercermin dalam seluruh aktivitas perusahaan.

\section{Tahap Evaluasi}

Tahap evaluasi adalah tahap yang perlu dilakukan secara teratur dari waktu ke waktu untuk mengukur sejauh mana efektivitas penerapan GCG telah dilakukan dengan meminta pihak independen melakukan audit implementasi dan scoring atas praktik GCG yang ada. Terdapat banyak perusahaan konsultan yang dapat memberikan jasa audit yang demikian, dan di Indonesia ada beberapa perusahaan yang melakukan scoring. Evaluasi dalam bentuk assessment, audit atau scoring juga dapat dilakukan secara mandatory misalnya seperti yang diterapkan di lingkungan BUMN. Evaluasi dapat membantu perusahaan memetakan kembali kondisi dan situasi serta capaian perusahaan dalam implementasi GCG sehingga dapat mengupayakan perbaikanperbaikan yang perlu berdasarkan rekomendasi yang diberikan.
4. Penerapan Prinsip Good Corporate Governance pada Bank Perkreditan Rakyat

Definisi Good Corporate Governance dari Cadbury Committe of the United Kingdom (1999) yakni: "seperangkat peraturan yang mengatur hubungan antara pemegang saham, pengurus (pengelola) perusahaan, pihak kreditur, pemerintah, pegawai serta para pemegang kepentingan intern dan ekstern lainnya yang berkaitan dengan hak-hak dan kewajiban mereka, atau dengan kata lain suatu sistem yang mengatur dan mengendalikan perusahaan (www.mucadvisory.com).

Masalah-masalah yang terjadi pada industri Perbankan di Indonesia yang apabila diamati akar penyebabnya (root causes) adalah lemah dan tidak diterapkannya tata kelola perusahaan yang baik (Good Corporate Governance). Hal ini menyebabkan industri Perbankan tidak dapat secara berhati-hati (prudent) menyerap pertumbuhan risiko kredit dan harga domestik yang cepat berubah. Sementara itu, tidak transparannya praktik dan pengelolaan (practices and governance) suatu bank mengakibatkan badan pengawas sulit mendeteksi praktik kecurangan yang dilakukan oleh pengurus dan pejabat bank.

Hal tersebut pula yang terjadi pada BPR. Misalnya saja yang terjadi pada PD BPR Badan Kredit Kecamatan Kaligesing. Kamijan, mantan pegawai PD BPR Badan Kredit Kecamatan Kaligesing diganjar hukuman satu tahun dua bulan penjara dan membayar uang pengganti sebesar Rp. 173.200.000,- oleh majelis hakim Pengadilan Negeri Purworejo. Dalam putusannya hakim menilai terdakwa terbukti bersalah melakukan tindak pidana korupsi penggelapan dana nasabah. Terdakwa juga di vonis membayar denda sebesar $\mathrm{Rp}$. 50.000.000,- subsider tiga bulan penjara serta membayar uang pengganti sebesar Rp. 


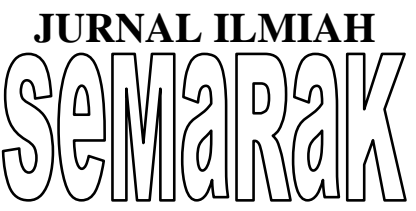

173.285.342,-. Bila dalam waktu satu bulan terdakwa tidak mampu membayarnya, maka harta disita atau kalau tidak punya harta, maka diganti hukuman enak bulan penjara. Dari hasil pemeriksaan sejumlah saksi selama persidangan, terdakwa selaku Kepala Seksi Pemasaran PD BPR Badan Kredit Kecamatan Kaligesing, telah merekayasa pengajuan permohonan kredit atas nama nasabah Wagiyem dan kawan-kawan sebanyak 26 nasabah. Modusnya, terdakwa meminjam dokumen nasabah untuk permohonan pengajuan kredit dan melebihi plafon dengan menggunakan jaminan orang lain. Jumlah total yang dicairkan dan dinikmati terdakwa sebesar Rp. 244.047.000,-. Selain itu terdakwa masih menggelapkan angsuran kredit nasabah senilai Rp. 20.457.000,- dan setoran tabungan nasabah sebesar Rp. 12.678.177 sehingga jumlah yang dipakai total mencapai Rp. 277.182.177,-. Untuk menutupi perbuatannya, terdakwa berpura-pura mengangsur senilai Rp. 90.123.700,- seolaholah dari nasabah. Pada praktiknya tidak hanya PD BPR di atas yang melakukan penggelapan dana nasabah, masih banyak lagi BPR-BPR lainnya yang melakukan hal serupa.

Sebagaimana yang telah dijelaskan bagaimana kasusnya di atas. BPR tersebut tidak menerapkan asas yang terkandung pada prinsip Good Corporate Governance dengan baik, masih banyak aturan-aturan pada asas-asas tersebut yang belum dilaksanakan, sehingga pengelola BPR tersebut dapat dengan leluasa melakukan suatu kejahatan Perbankan dan badan pengawas (Bank Indonesia) tidak dapat mendeteksi adanya praktik-praktik curang yang dilakukan BPR tersebut.

Komite Nasional Kebijakan Corporate Governance (yang selanjutnya disebut KNKCG) telah mengeluarkan Pedoman Good Corporate Governance, yang selanjutnya KNKCG mengeluarkan pedoman yang lebih spesifik, yaitu Pedoman Good Corporate Governance Perbankan Indonesia pada tahun 2004. Pedomanpedoman tersebut dibuat dengan tujuan agar menjadi acuan bagi seluruh perusahaan untuk dapat melaksanakan Good Corporate Governance. Pedoman Good Corporate Governance Perbankan Indonesia dapat dipergunakan oleh BPR dalam melaksanakan Good Corporate Governance dengan lebih baik.

Menjawab permasalahan-permasalah penerapan Good Corporate Governance pada BPR, Pedoman Good Corporate Governance Perbankan Indonesia telah mengatur mengenai pedoman praktis pelaksanaan Good Corporate Governance yang dapat dijadikan acuan oleh bank dalam melaksanakan Good Corporate Governance. Pelaksanaan Good Corporate Governance dapat dilakukan melalui lima tindakan yaitu:

a. Penetapan visi, misi dan corporate values

Visi adalah suatu pandangan jauh tentang perusahaan (bank), tujuan-tujuan perusahaan (bank) dan apa yang harus dilakukan untuk mencapai tujuan tersebut pada masa yang akan datang. Misi adalah pernyataan tentang apa yang harus dikerjakan oleh perusahaan (bank) dalam usahanya mewujudkan visi. Misi juga akan memberikan arah sekaligus batasan proses pencapaian tujuan sedangkan corporate values merupakan nilai-nilai yang di anut oleh suatu perusahaan (bank) yang di dalamnya juga mengatur mengenai prinsip Good Corporate Governance dan corporate values ini terdiri dari kepuasaan pelanggan (nasabah) atau klien, kualitas atau keunggulan mutu perusahaan (bank), pengembalian asset, penggunaan teknologi untuk penguasaan pasar, nilai pegawai atau kualitas pegawai perusahaan (bank) tersebut. Penetapan visi, misi dan corporate values merupakan langkah awal yang harus 


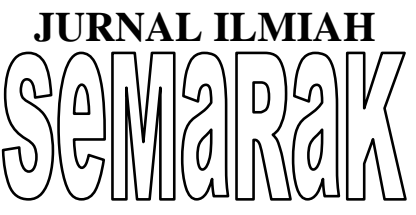

dilaksanakan dalam penerapan Good Corporate Governance oleh suatu bank.

\section{b. Penyusunan corporate governance structure \\ Corporate governance structure} mengatur pembagian hak dan kewajiban pada masing-masing pihak yang berbeda dalam perusahaan, seperti komisaris, Direksi, dan pemegang saham, dan menerangkan mengenai peraturan dan prosedur untuk menyusun keputusan dalam kepentingan perusahaan. Corporate governance structure dapat ditetapkan secara bertahap dan terdiri dari sekurang-kurangnya

1) Kebijakan corporate goverenance yang selain memuat visi dan misi bank, juga memuat tekad untuk melaksanakan Good Corporate Governance dan pedomanpedoman pokok penerapan prinsip Good Corporate Governance yaitu Transparrency, Accountability, Responsibility, Independency dan Fairness.

2) Code of Conduct yang memuat pedoman perilaku yang wajar dan dapat dipercaya dari pimpinan dan pegawai bank.

3) Tata Tertib Kerja Dewan Komisaris dan Tata Tertib Kerja Direksi yang memuat hak dan kewajiban serta akuntabilitas dari Dewan Komisaris dan Direksi maupun para anggotanya masingmasing.

4) Organisasi yang di dalammya tercermin adanya risk management, internal control dan compliance. Pengimplementasiannya adalah dengan membentuk badan-badan pada perusahaan (bank) tersebut yang berfungsi untuk membuat suatu kebijakan yang terkait dengan risk management, internal control dan compliance.

5) Kebijakan risk management, audit dan compliance. a) Risk management menurut Djohanputro (2008 : 43) merupakan proses terstruktur dan sistematis dalam mengidentifikasi, mengukur, memetakan,mengembangkan alternatif penanganan risiko, dan memonitor dan mengendalikan penanganan risiko.

Sedangkan menurut Fahmi (2010:2) manajemen risiko adalah suatu bidang ilmu yang membahas tentang bagaimana suatu organisasi menerapkan ukuran dalam memetakan berbagai permasalahan yang ada dengan menempatkan berbagai pendekatan manajemen secara komprehensif dan sistematis.

Pemahaman manajemen risiko memungkinkan manajemen untuk terlibat secara efektif dalam menghadapi uncertainty dengan risiko dan peluang yang berhubungan dan meningkatkan kemampuan organisasi untuk memberikan nilai tambah.

a) Audit menurut Mulyadi (2013 : 9) adalah suatu proses sistematik untuk memperoleh dan mengevaluasi bukti secara objektif mengenai pernyataan pernyataan tentang kegiatan dan keterjadian ekonomi, dengan tujuan untuk menetapkan tingkat kesesuaian antara pernyataan pernyataan tersebut dengan kriteria yang telah ditetapkan, serta penyampaian hasil-hasilnya kepada pemakai yang berkepentingan.

b) Compliance adalah kepatuhan yang kaitannya dengan kesesuaian antara sikap para organ perusahaan baik pemegang saham, Direksi, komisaris, pegawai maupun stakeholders lainnya, dengan 


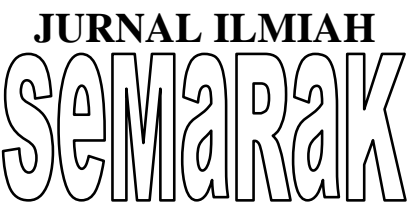

peraturan perundang-undangan yang berlaku dan juga peraturan internal perusahaan (bank). Bank yang lalai menjalankan peran dan fungsi kepatuhan akan berhadapan langsung dengan apa yang dikenal dengan compliance risk. Bank Indonesia mendefinisikan risiko kepatuhan sebagai risiko yang timbul akibat bank tidak mematuhi dan/atau tidak melaksanakan peraturan perundang-undangan dan ketentuan yang berlaku. (www.bankernote.com)

6) Human resources policy yang jelas dan transparan. Peraturan ini berlaku bagi seluruh pihak yang terkait dengan perusahaan (bank) tersebut, mulai dari pemegang saham, komisaris, Direksi maupun stakeholders lainnya.

7) Corporate plan yang menggambarkan arah jangka panjang yang jelas. Corporate plan ini berkaitan dengan tujuan-tujuan dan nilai-nilai yang akan di capai oleh perusahaan (bank) tersebut.

c. Pembentukan corporate culture

Pembentukan corporate culture untuk memperlancar pencapaian visi dan misi serta implementasi corporate governance structure. Corporate culture terbentuk melalui penetapan prinsip dasar (guiding principles), nilai-nilai (values) dan norma-norma (norms) yang disepakati serta dilaksanakan secara konsisten dengan contoh konkrit dari pimpinan bank. Corporate culture perlu di diskusikan secara berkesinambungan dan ditunjang oleh social communication.

d. Penetapan sarana public disclosures Pembentukan pola dan sarana disclosure sangat diperlukan sebagai bagian dari akuntabilitas bank kepada stakeholders. Sarana disclosure dapat melalui laporan tahunan (annual report), situs internet (website), review pelaksanaan Good Corporate Governance dan sarana lainnya.

e. Penyempurnaan berbagai kebijakan bank sehingga memenuhi prinsip Good Corporate Governance Usaha penyempurnaan berbagai kebijakan yang terkait dengan prinsip Good Corporate Governance merupakan tanggung jawab dari pihak Negara yang memiliki otoritas membuat suatu kebijakan ataupun peraturan perundang-undangan yang dapat berlaku di Indonesia.

Selain pelaksanaan pedoman praktis di atas, agar bank dapat melaksanakan Good Corporate Governance secara efektif, juga memerlukan lingkungan yang kondusif, untuk itu maka pihak-pihak yang terkait dengan Perbankan perlu memberikan dukungan, yaitu pihak negara, bank dan masyarakat.

Pihak negara yang berarti pemerintah melalui Bank Indonesia perlu membuat peraturan mengikat tentang pelaksanaan Good Corporate Governance yang ditujukan bagi BPR, seperti halnya pada bank umum. Apabila ada peraturan yang mengikat dan ada sanksi maka BPR akan melaksanakan Good Corporate Governance dengan lebih baik. Bank Indonesia sebagai regulator perlu terus menerus melakukan berbagai upaya secara konsisten terutama dalam memperkuat pelaksanaan Good Corporate Governance, menyempurnakan aspek pengaturan dan pengawasan, mendorong penyehatan BPR bermasalah, memperkuat struktur governance BPR, menciptakan iklim kondusif bagi perkembangan BPR maupun mendukung penguatan infrastruktur industri. Seluruh upaya tersebut dikonsolidasikan untuk menciptakan Perbankan Indonesia yang memiliki daya saing yang teruji kehandalannya. Menurut Herlianto, secara tegas mengemukakan bahwa untuk mewujudkan peran Bank Indonesia dalam pengaturan penerapan Good 


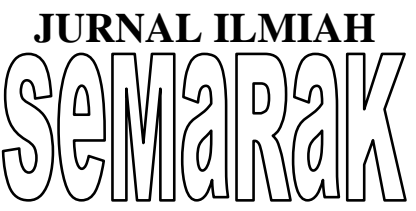

Corporate Governance di dunia Perbankan, perlu dibangun suatu strategi yang diarahkan untuk mendorong internal governance yang sehat dan lingkungan eksternal yang kondusif di mana instrumennya tidak lain adalah ketentuan-ketentuan yang berkenaan dengan prinsip-prinsip Good Corporate Governance. ((Moh. Wahyudin Zarkasyi, $2008: 7$ ).

Pihak BPR itu sendiri dapat memberikan dukungan dengan cara melaksanakan 5 (lima) asas Good Corporate Governance dengan seutuhnya dan mempergunakan Pedoman Good Corporate Governance Perbankan Indonesia sebagai pedoman pelaksanaan, lalu Pedoman Good Corporate Governance Perbankan Indonesia diimplementasikan dengan membuat code of conduct sebagai pedoman perilaku yang wajar, patut dan dapat dipercaya dari seluruh jajaran bank. Code of conduct memuat sekurang-kurangnya:
a. Pedoman tentang benturan kepentingan (conflict of interest)
b. Kerahasiaan yang harus dipelihara
c. Hal-hal yang tergolong penyalahgunaan jabatan
d. Integritas dan akurasi data
e. Pernyataan tahunan (annual disclosure)
f. Sanksi pelanggaran dan ketidakpatuhan

BPR juga harus memiliki internal control yang baik. Bank umum biasanya memiliki direktur kepatuhan yang berfungsi mengawasi pelaksanaan Good Corporate Governance internal bank dan mengawasi segala kegiatan pegawai sesuai dengan peraturan perUndang-Undangan yang berlaku, sehingga apabila Good Corporate Governance belum dilaksanakan dapat diperbaiki dengan lebih cepat. Peningkatan kualitas Sumber Daya Manusia juga salah satu faktor penting, karena Good Corporate Governance dapat terwujud apabila Sumber
Daya Manusia pada bank tersebut memiliki kualitas yang baik dan harus selalu dilakukan peningkatan kualitas Sumber Daya Manusia melalui pelatihan-pelatihan, karena di dalam Pedoman Umum Good Corporate Governance disebutkan bahwa pelaksanaan Good Corporate Governance dapat didorong dari dua sisi, yaitu etika dan peraturan. Etika terkait pada kualitas dan dorongan dari individu-individu diantaranya pegawai bank, pimpinan dan stakeholder lainnya. BPR juga perlu membentuk pola dan sarana disclosure yang sangat penting dan merupakan bagian dari akuntabilitas bank kepada stakeholder. Sarana disclosure tersebut dapat melalui laporan tahunan (annual report), situs internet (website), review pelaksanaan Good Corporate Governance dan sarana lainnya. Sangat sedikit BPR yang memiliki situs internet sehingga nasabah kesulitan untuk mengakses laporan-laporan keuangan BPR.

Masyarakat juga harus melatih kepekaan terhadap pelaksanaan Good Corporate Governance pada bank, karena apabila bank tidak melaksanakan Good Corporate Governance maka nasabahlah yang akan dirugikan, sehingga kepekaan dan pengetahuan masyarakat mengenai hak dan kewajiban bank terhadap nasabah perlu ditingkatkan pula.

Berdasarkan pemaparan di atas, maka pelaksanaan Good Corporate Governance yang efektif bagi BPR adalah dengan melaksanakan pedoman praktis yang diatur dalam Pedoman Good Corporate Governance Perbankan Indonesia, serta hal yang tidak kalah penting adalah peran serta dari Negara, bank dan masyarakat dalam partisipasi pelaksanaan Good Corporate Governance. Lingkungan yang kondusif dapat mendorong pelaksanaan Good Corporate Governance yang efektif dan lebih baik.

Dengan pelaksanaan Good Corporate Governance yang efektif maka akan 


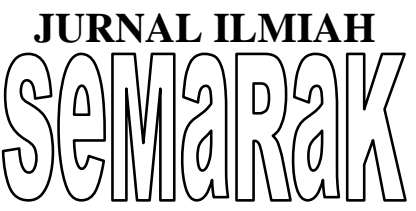

Jurnal Semarak,Vol. 1,No.1,Februari 2018 , Hal (130-141)

@ Prodi Manajemen Fakultas Ekonomi Universitas Pamulang

meningkatkan kualitas Sumber Daya Manusia pada BPR. Dengan kualitas Sumber Daya Manusia yang baik maka akan meningkatkan pelayanan bank kepada nasabah. Selain itu, meningkatkan pula pengawasan baik secara internal maupun eksternal bank, sehingga mengurangi kemungkinan terjadinya kejahatan perbankan pada BPR. Hal ini merupakan bentuk dari perlindungan hukum terhadap nasabah BPR.

\section{KESIMPULAN DAN SARAN Kesimpulan}

Pelaksanaan Good Corporate Governance pada BPR di Indonesia belum terlaksana dengan baik. Dapat dibuktikan dengan masih banyaknya kerugian yang di alami oleh nasabah bank di akibatkan karena kualitas SDM yang kurang baik dan profesional pada BPR. Lingkungan yang kondusif dapat mendorong pelaksanaan Good Corporate Governance yang efektif dan lebih baik. Dengan pelaksanaan Good Corporate Governance yang efektif maka akan meningkatkan kualitas Sumber Daya Manusia pada BPR. Dengan kualitas Sumber Daya Manusia yang baik maka akan meningkatkan pelayanan bank kepada nasabah. Selain itu, meningkatkan pula pengawasan baik secara internal maupun eksternal bank, sehingga mengurangi kemungkinan terjadinya kejahatan perbankan pada BPR. Hal ini merupakan bentuk dari perlindungan hukum terhadap nasabah BPR.

\section{Saran :}

1. Menyarankan agar Pedoman Good Corporate Governance Perbankan Indonesia direalisasikan menjadi sebuah peraturan perundang-undangan yang memiliki sanksi dan memiliki kekuatan hukum mengikat bagi BPR di seluruh
Indonesia.

2. Membentuk direktur kepatuhan bagi BPR dalam upaya meningkatkan pengawasan internal bank dalam pelaksanaan Good Corporate Governance agar penyelewengan ataupun kejahatan perbankan dapat diminimalkan.

3. Meningkatkan pengawasan Good Corporate Governance oleh Bank Indonesia kepada bank umum maupun BPR dan meningkatkan peranan lembaga yang telah ada agar pelaksanaan Good Corporate Governance di Indonesia dapat ditingkatkan.

4. Meningkatkan kesadaran dan partisipasi baik Negara, bank dan masyarakat melalui perubahan sistem pengawasan, manajemen bank dan kepekaan masyarakat.

\section{Daftar Pustaka \\ Buku}

Djohanputro. (2008). Manajemen Risiko Korporat. Jakarta: PPM Manajemen.

Fahmi, Irham. (2010). Manajemen Risiko. Bandung: Alfabeta.

Hermansyah. (2008). Hukum Perbankan Nasional Indonesia. Jakarta: Kencana Prenada Media Group.

Muhammad, Abdulkadir. (2006). Hukum Perusahaan Indonesia. Bandung: PT. Citra Aditya Bakti.

Mulyadi, (2013). Sistem Akuntansi. Jakarta: Salemba Empat.

Nazir, Mohammad. (1988). Metode Penelitian. Jakarta: Ghalia Indonesia.

Shaw, John.C. (2003). Corporate Governance and Risk: A System Approach. New Jersey: John Wiley \& Sons,inc

Sugiyono. (2005). Memahami Penelitian Kualitatif. Bandung: Alfabeta. 


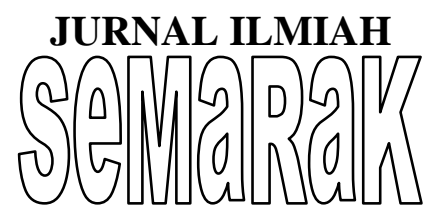

P-ISSN 2615-6849

Jurnal Semarak,Vol. 1,No.1,Februari 2018 , Hal (130-141)

@ Prodi Manajemen Fakultas Ekonomi Universitas Pamulang

Usma, Rachmadi. (2001). Aspek-Aspek

Hukum Perbankan Indonesia. Jakarta:

Gramedia Pustaka Utama.

Wicaksono, Frans Satrio. Tanggung Jawab

Pemegang Saham, Direksi dan

Komisaris Perseroan Terbatas (PT).

Jakarta: Visimedia.

Zarkasyi, Moh. Wahyudin. (2008). Good Corporate Governance. Bandung:

Alfabeta.

\section{$\underline{\text { Jurnal }}$}

Kaihatu,Thomas S. Good Corporate Governance dan Penerapannya di Indonesia.http://jurnalmanajemen.petra .ac.id/index.php/man/article/view/1650 5/16497. Universitas Kristen Petra Surabaya.

\section{$\underline{\text { Sumber Internet }}$}

"Bank", diakses melalui http://dspace.widyatama.ac.id, Kamis, 9 November 2017, $11.03 \mathrm{Wib}$

"Pedoman Umum Good Corporate Governance Indonesia 2006”, diakses melalui www.bapepam.go.id, Selasa, 7 November 2017, 10.47 Wib.

"Good Corporate Governance", diakses melalui www.muc-advisory.com, Sabtu, 11 November 2017, 18.43 Wib

"Bank Compliance", diakses melalui www.bankernote.com, Kamis, 25 Januari 2018, 09.45 Wib 